\title{
BEYOND HUMAN: THE FLIGHT TOWARDS AN ANIMAL IN THE CENTRAL EUROPEAN/CZECH LITERATURE (ČAPEK, KUNDERA-KAFKA, HAŠEK)
}

By Jan Matonoha, (Institute for Czech Literature, Czech Academy of Sciences, Prague)

The objective of this paper is to argue — to put it somewhat emphatically—-that European culture and society regards humanity highly while at the same time degrades and mutilates animals, physically or epistemologically, by exploiting, venerating and pampering them. As the paper tries to argue, these cultural and social attitudes would benefit from the radically deterritorializing schizophrenic treatment of Deleuze as it is anticipated in the works of two Central European modernist authors, Franz Kafka and Jaroslav Hašek.

As to the outline of the paper, I would like to make few brief notes on the passage from the Nietzschean to Deleuzian tradition of an anti-humanist thinking (provided these two can be at all seen as distinct and separate), as well as on the anti-humanist topoi in Western and Central European literature. Second, on the backdrop of this brief and fragmented observation on the genealogy of anti-humanist writing, I would like to offer a further discussion of texts of the four Czech (or Central European) authors I indicate in the paper's title.

As mentioned, I shall start with the comparison of two pivotal thinkers of continental anti-humanism, Friedrich Nietzsche and Gilles Deleuze. Any thorough assessment of their work in terms of its anti-humanist tradition would be way beyond the possibilities of this paper. Suffice it to say, the Nietzschean radical critique and debunking of a conventional humanist tradition in his Human, All too human, The Gay Science, Thus Spoke Zarathustra, Beyond Good and Evil, On the Genealogy of Morality etc. showed that the mastery of man is mostly founded not in his insight, sovereignty and gained respect, but on the reductive, logocentric epistemic and technological annihilation of radical Otherness, the Otherness that transcends the stable system of human emotional, ethical and epistemological categories. The reductive logocentric nature of human cognition, the way of our seeing, approaching and treating reality is practiced through deploying an army of one-dimensional and anthropocentric metaphors, which is anecdotally reflected in the wisecracks such as "The will to a system is the lack of integrity" (Nietzsche 1983: 36). The logocentric discourse of our culture was in Nietzsche's own books countered and challenged by a different type of writing_écriture - as Jacques Derrida showed convincingly in his Spurs. In Nietzsche's writing there are various conflicting and ambiguous metaphors that aim to represent the type 
of identity that eludes designation, to gesture towards a radical Otherness that escapes all possible philosophical signification. This figurative place is occupied variably by tricky, dangerous yet infinitely appealing elements of water, or by the feminine. Entering the middle stage of his philosophical development, Nietzsche rejects his earlier allzumenschliches fascination with the possibility of a radical romantic protest and counter-position. To criticize and protest does not suffice; what is needed is a radical break from the logic of values that so far had been taken to be worthy enough to be doubted and thus paradoxically cemented in their legitimacy (albeit as a targets of a critique).

This move-rewriting the rules of a game entirely_can be also tracked down in Deleuzian polemics with Lacanian psychoanalysis. The Deleuzian schizo finds the paternal figure not only unworthy of conflict, he does not even develop a framework for signification within which a father figure could operate and be noticed. The Nietzschean metaphorical positioning of a woman as a figure that transgresses the conventional concept of stable, unified, manageable and comprehensible subjectivities and cognitive processes is to be replaced with yet another, even more radical concept, that of an inhuman: machines, bodies without organs, a schizo that breaks away from the Oedipus figure and searches from the lines of flight from the system of territorialization towards an inhuman. ${ }^{1}$

On the backdrop of these discourses of de-centered human subjects in "postNietzschean" philosophy, I would like to explore the theme of the animal in the works of fiction by few Central European / Czech writers. I will contrast, on the one hand, the works of Karel Čapek and Milan Kundera as the instances of a conventional humanist treatment of the topic of animals with, on the other hand, a less "regular" approach of an unlikely couple of quite different yet in many regards intriguingly similar authors - Franz Kafka and Jaroslav Hašek. However, I feel that a few words need to be said first concerning the tradition of Western and Central European literature as it pertains the topic of the flight from authority and mythology of humanism.

In particular, the French modernist tradition of the de-centering subjectivity and the human body deals with fragmented organs in a specific manner. For the sake of the brevity I shall skip here to the fiction of Louis-Ferdinand Céline, Antonin Artaud or Jean Genet just to mention the way, as in Georges Bataille's Story of the Eye, the attention focuses on the

\footnotetext{
${ }^{1}$ No need to mention here the way this tradition of thinking was further developed by feminist philosophy, among others in Donna Haraway's concept of a cyborg identities (Haraway 1991) or Rosi Braidotti's nomadic subjectivities (Braidotti 1994). With respect to the prime sake of my argument here I set aside other paradigm accounts of the human-inhuman relation as put forward by authors such as Jacques Derrida (Derrida 2002) or further reflections on and elaboration of his approaches in works of Cary Wolfe (Wolfe 2003) to mention just two representatives of current post-humanist thinking.
} 
annihilation of a subject through aggressively seductive pleasures of a gaze, of seeing and being seen (which are being followed by a more direct violence) and on alternative pleasures of tactile nature (Bataille 1977). Equally, the demarcation of subjectivity is being put under test here through its transgression and immersion into what Kristeva called an abject, the "thing" that is simultaneously inside and outside of a body, subjectivity and, more importantly, outside of the symbolic, cultural system (Kristeva 1982).

These are of course by no means the only significant treatments of the given topic in literature. As already suggested, the turn of the century and early modernist as well as avantgarde Central European literature abounded with various literary treatments of the bodily human existence verging on the inhuman. For instance, Franz Kafka, for example, in the Description of a Struggle, The Cares of Family of Man, The Metamorphosis etc., or Witold Gombrowicz, in Ferdydurke, pursued the path of fragmenting the image of human body radically in an expressionist vein: individual human body parts, hands, legs, calf or buttocks for that matter (in Gombrowicz writings) became not that much a synecdoche of an individual as a means of the de-centering of a human subjectivity (Kafka 1971; Gombrowicz 1961). This grotesque, absurd and uncanny imagery helped to highlight the way our existence is inevitably located in a bodily situation, debunking the sublime aspiration for a dignified detachment and autonomy of the Self from its inconvenient material and yet at the same always already culturally determined or negotiated condition. Reading Kafka and Gombrowicz, we can get the clear sense of the ways we are being interpellated, confronted or violated by the gaze of others based on our material appearance and habitus (to use Pierre Bourdieau's term). These images of fragmentation of bodily existence can be successfully read as a move towards Deleuzian demise of a subject and emergence of the body without organs conceived as a flow of multiple energies (cf. Deleuze and Guattari 1983).

Following these brief and general introductory remarks, I would like to embark on the debate of the writing of the four Central European authors mentioned in the title of this paper. I shall start with Karel Čapek and Milan Kundera as two symptomatic representatives of literary writing of traditional humanist vein to further proceed to the discussion of the writing of Franz Kafka and Jaroslav Hašek . Interestingly enough, in his plays and novels, Nobel Prize nominee Karel Čapek frequently dealt with the topic of animals and machines. Coincidentally, he is often mistakenly credited with coining the word "robot" which was actually made up by his younger brother Josef, a co-author of his many plays and early short stories. However, the motifs of animals and machines are used in Čapek's works merely as traditional allegories whose point of reference is always their unmistakably and 
conventionally human counterparts. These are the cases of Rossum's Universal Robots from 1920, where the word "robot" first appeared, Pictures from the Insects' Life (1921) or War with the Newts (1936), where machines, beetles and newts designate human sentiments, narrow minded or selfish petit bourgeois and Nazi Germany soldiers, respectively. Perhaps few of his more intriguing observations stemming from his humanist leanings is his profound skepticism about grand and potentially totalitarian ideologies, the skepticism quite nicely encapsulated in the title of English volume of his writing in Toward the Radical Center (Čapek 1990) could be read as a sign of the radically relativist and essentially undecidable nature of human justice and social arrangements. Čapek's deeply ingrained skepsis about the nature of justice is one of the points of his thinking I find quite interesting. In the story "Last Judgment" (Čapek 1994), there is depicted a figure of God who systematically and deliberately abstains from passing any judgment precisely since he $i$ s omniscient. Perhaps one of the rare insights about the limits of human vis-a-vis otherness could be found in his story Footprints (ibid.) which deals with the nature of mystery. The story disproves the idea that the true mystery is, for instance, a murder: for murder is actually a perfectly illuminated slice of life, as the narrator in the story puts it. A true mystery according to Capek resides rather in the everyday being of our fellow travelers, in the radical Otherness and silence of our closest one: you are never really going to learn what your spouse or your cat thinks, Čapek says in the story.

Not unlike Karel Čapek's (cf. namely the novel Hordubal), Milan Kundera's writing is known for debunking the idea of any possibility of successful communication and understanding. In Kundera's universe, we all fall prey to the differential nature of language and are never exempted from the fate of constant misunderstandings and misconceptions about our close ones and mostly ourselves. Yet there is one exceptional place in Kundera's universe that is elevated from this ill fate of human condition. It is the topoi of a silent, impenetrable Other, variably — and symptomatically enough — occupied by either a female figure (Lucie in The Joke, Kundera 1992) or an animal, namely a dog (Karenin in The Unbearable Lightness of Being, Kundera 1996). But precisely at this very point Kundera not only profoundly contradicts his critique of kitsch: his treatment of these characters amounts to emotional blackmail perfectly conforming his own definition of a kitsch, i.e. - the state we are emotionally moved by the fact we are able to be moved. More importantly, without realizing it, Kundera effaces any form of otherness (which he sets out to celebrate) by projecting human sentiments into the silent character of Karenin, a dog, pretty much in the same way he projects narrator's and reader's sentiments into the violated female body of a 
silent character of Lucie in his first novel The Joke. Lucie has no voice and thus is on the one hand exempted from the vicious nature of communication, while on the other, at the very same time serves as a perfect empty screen for one's kitschy and self-indulging emotional projections. In Kundera's fictional universe, the silence of otherness is always audible only in relation to territorialized domain of human values and system of thought. Although both Čapek and Kundera implicitly yet emphatically renounce the Cartesian idea of an animal as a machine in their writing, they are stuck in the conventional appraisal of animals for which animals exist only insofar as they could be translated into values comprehensible to the established humanist system of thought.

In terms of the treatment of the topic of animals and inhuman, the writing of Karel Čapek and Milan Kundera could be juxtaposed and put in contrast with that of their somewhat earlier literary predecessors, Franz Kafka and Jaroslav Hašek. Kafka, an author of an essentially multiple, heterogeneous, de-centred and deterritorialized identity (conventionally grasped through a somewhat simplistic metaphor of a triple ghetto) staged a numerous instances of the inhuman in his writing. Several possible lines of reading the inhuman into Kafka can be demarcated by the keywords of a machine, of the uncanny, or an animal. I shall briefly take a look at all of them respectively.

Kafka's critical and uncanny travesties of modern bureaucratic machinery and institutional logic organizing society might point not only towards the theme of alienation from society and from one's subjectivity, but also to the radical flight away from mancentered systems of thought, organization and governance. At the same time, however, Kafka reveals the profound dependence of our society on various dispositives of biopower. One might rather counter-intuitively claim that the executing machine in The Penal Colony (Kafka 1971) is not at all an inhuman tormenting instrument, but, on the contrary, the very manifestation of the all too human allzumenschliches nature of a man. The machine basically demonstrates or materializes the will to knowledge, the will to decidable categories, logocentric truths, the thirst to learn the grounds of one's original sin (which according to Kafka is established performatively by the very enunciation of the claim for one's alleged innocence), the thirst displayed both by the officers and-in a way unsurprisingly in the Kafkesque universe- by the convicts themselves. In essence, the tormenting machine manifests a paradoxical, and yet, as Judith Butler showed in her Psychic Life of Power (Butler 1997), an inevitable will on the part of man to be disciplined at any cost, even at the cost of the destruction of one's living body. 
As to the motif of the uncanny, it can be said there are numerous uncanny subjects in Kafka's writing. Paradigm examples of uncanny subjects include a creature called Odradek in the Cares of a Family Man and the character of Gregor Samsa from The Metamorphosis (Kafka 1971). Odradek and Gregor are something that belongs tightly to a household or to a family yet that has at the same time become infinitely strange. Odradek and Gregor Samsa are deterritorialized subject—or more precisely, abjects_epitomized: they are rejected, expelled, cast out yet they keep returning, and by their stubborn existence they keep reminding the center, the system, the majority of both its authoritative negating gesture of rejection as well as of its merely transitory, contingent nature.

While animal motifs and topoi abound in Kafka's stories (cf. A Giant Mole, A New Advocate, The Burrow, Investigations of a Dog, The Vulture, Josephina the Singer, or the Mouse Folk), the inhuman creatures seem to serve there mostly as parables and allegories denoting the corrupt, annoying, counterproductive and self-destructive forces of the human psyche. For instance, The Burrow can be read as a hilarious and at the same time chilling allegory of a human petit mindedness that desperately and counter-productively seeks to secure its existence in an inherently insecure world. The chilling moments of the story come from the moments of paradoxical yet verisimilar depictions of self-destructive behavior of the underground creature (c.f. for example that the only way the creature is willing to proof the solidity of the newly built walls and ceiling is by running against the walls with its forehead until it starts to bleed). The Metamorphosis represents an exception here, though, at least in the Deleuze's and Guattari's reading (Deleuze and Guattari 1975). One line of interpretation is to read The Metamorphosis as the story of alienation within a family, or rather a story of the family's inability to cope with otherness. More productively, it may be read as the story of a downright abuse of otherness for the sake of gathering greater symbolic capital as in the case of Gregor Samsa's sister, in whose case we can observe the logic of deconstructivist reversals at work. If one takes the issue under consideration one step further, the phenomenon turns into its exact opposite. In this particular case we can see the way the sister's unique understanding and sensitivity towards Gregor turns soon to the perfect means of self- aggrandizement and ways of gaining social and symbolic capital and power over both Gregor and the whole family. In the Deleuzian reading (Deleuze and Guattari 1975), which is a reading that can be seen as a paramount example of embracing the inhuman, the uncanny experience of Gregor Samsa's failed humanity is not the case of tragic alienation but rather a failure to follow the line of flight from a human form towards a radically de-territorialized subjectivity of an animal. The real essence of Gregor Samsa's tragedy does not reside in the fact that he turned 
into a giant insect, but precisely because he did not turn himself into this insect thoroughly enough.

The last author I would like to discuss here is Jaroslav Hašek. Compared to Čapek or Kundera, Hašek, a radical satirist, had a radical and rather skeptical view of the human condition. Although not occupying the many multiple identities as his compatriot and contemporary, Franz Kafka (both were born in the very same year and Hašek died, a heavy drinker, an alcoholic, one year prior to Kafka), Hašek might be seen as a fairly deterritorialized subject too, not only given the fact he was a branded national traitor, Bolshevik (fighting against Czechoslovakian army that itself contributed to the foundation of an independent Czechoslovakia following the end of WW I), a bigamist (while actually most likely a gay), but also a self-appointed executioner, as it is quite probable he personally ordered numerous executions without trial while he served as commissar of Soviet Red Army in the town of Ufa in region of Bashkiria (at southwestern Ural) during the Russian civil war. Hašek was by no means an author of one book, the well-known satiric novel The Good Soldier Švejk: and his Adventures in the World War (Hašek 2000). On the contrary, he was a highly prolific writer, mostly due to the fact he needed to earn enough money to get himself enough alcohol - the novel The Good Soldier Švejk was actually published in paperback installments and remained unfinished after Hašek died in Lipnice in southeast Bohemia (paradoxically enough while spending the last years of his life drowning in alcohol in the local Lipnice hotel and restaurant where he moved precisely in order to escape excessive drinking in Prague pubs).

Švejk might epitomize (albeit in a somewhat reductive mode) a Butlerian idea of performative parodical resistance (Butler 1993). Švejk resists his ill predicament of a private in the world war by the strategy that does not try to challenge but rather ridicules rigid authority. Švejk flees the limits of the system's framework through the means of its grotesque affirmation that reveals true absurdity and arbitrariness of bureaucratic and military machinery. It might be added that there seems to be another post-structuralist link in the Good Soldier Švejk: intriguingly, although a war novel set in the break of WWI, its plot is mostly located not on the battlefield but indoors in the paradigm Foucauldian institutions of modernity such as barracks, prison houses, clinics, asylums, courthouses etc.

As to the theme of animals, it is almost omnipresent in Hašek's writing and biography. At one point of his colorful career, which he spent mostly as a freelance journalist, he was employed as an editor and writer for a popular journal The World of Animals. His work there was quite interesting, as he not only succeeded in negotiating a regular and free supply of beer 
right into his office, but as he indulged in rather fantastic journeys into the spheres of zoology and etiology. Some of his more memorable expert treatise on animal behavior included original - and completely made up — research into intricacies of alcoholism and the sexual life of apes. The protagonist of Hašek's most famous piece of writing, the good soldier Švejk earns his living on selling mongrel dogs with forged pedigrees. The theme of dogs meanders through Hašek's writing quite extensively. On a metaphorical level, Peter Steiner labeled the character of Švejk a Cynic hero (Steiner 2000), where a cynic is derived of the word cynos, a dog referring both to the Ancient Greek school of thought and to Švejk's cynical attitude towards the traditional morality, to the state apparatus as well as ideologies and grand narratives of history. From the very beginning, Švejk was clearly an underdog. But by his specific survival discourse and behavioral strategies, he managed to turn himself into a dog. One might say that one admittedly anthropocentric metaphor used by Reynhard Heydrich (the architect of the final solution and the so called Reichsprotektor of Bohemia and Moravia during the WWII, assassinated in Prague in 1942) in reference to Czech mentality could be used to describe very own Švejk's nature. Heydrich once claimed about Czechs famously they are incalculable laughing beasts. Švejk is such a creature, a (dionysiacly?) laughing beast is something that might be seen as successfully confronting the deeply ingrained notion of humanity.

I would like to conclude here with yet another arguably central European author, German writer Ingeborg Bachmann. Her text “All” (Bachmann 1987) tells a story of a father who prefers his child not to learn the language of humans but rather a language of silent things such as stones. Ultimately the father is paradoxically glad and relieved that the child dies by accident, and was young enough not to be able to acquire and master his mother tongue properly. It seems that the Ingeborg Bachmann text can not only be read as a meditation on the issues of language, thinking and subjectivity (the issues she was intrigued by since her dissertation thesis on Wittgenstein and Heidegger) or as an implicit feminist statement on the myth of natural and unambiguously happy parenthood but also as a radical attempt to slip out from human subjectivity towards a deterritorialized, inhuman state of becoming-an-animal—or, more precisely_becoming-a-thing.

\section{WORK CITED}

Bachmann, Ingeborg. The Thirtieth Year: Stories. New York: Holmes \& Meier, 1987. 
Bataille, Georges. Story of the Eye. New York: Urizen Books, 1977.

Braidotti, Rosi. Nomadic Subjects: Embodiment of Sexual Difference in Contemporary Feminist Theory. New York: Columbia University Press, 1994.

Butler, Judith. Bodies that matter : on the discursive limits of "sex." New York: Routledge, 1993.

Butler, Judith. The psychic life of power : theories in subjection. Stanford, Calif.: Stanford University Press, 1997.

Čapek, Karel. Tales from Two Pockets. North Haven, CT: Catbird Press, 1994.

Čapek, Karel. Toward the Radical Center: A Karel C apek Reader. Highland Park, N.J.: Catbird Press, 1990.

Deleuze, Gilles, and Félix Guattari. Anti-Oedipus: Capitalism and Schizophrenia. Minneapolis: University of Minnesota Press, 1983.

Deleuze, Gilles, and Félix Guattari. Kafka: Toward a Minor Literature. Minneapolis: University of Minnesota Press, 1986.

Derrida, Jacques. "The Animal That Therefore I Am (More to Follow)." CRITICAL INQUIRY. 28 (2002): 369-418.

Derrida, Jacques. „Spurs. Nietzsche's Styles“, in Kamuf, P. (ed.): A Derrida Reader. Between the Blinds. New York: Harvester - Wheatsheaf, 1991.

Gombrowicz, Witold. Ferdydurke. New York: Grove Press, 1961.

Haraway, Donna. Simians, Cyborgs, and Women. The Reinvention of Nature. London: Free Association Books, 1991. 
Hašek, Jaroslav. The good soldier Svejk: and his fortunes in the world war. London: David Campbell Publishers, 2000.

Kafka, Franz. The Complete Stories. New York: Schocken Books, 1971.

Kristeva, J. and L. S. Roudiez. Powers of horror : an essay on abjection. New York:

Columbia University Press, 1982.

Kundera, Milan. The Joke. London: Faber and Faber, 1992.

Kundera, Milan. The unbearable lightness of being. London: Faber, 1996.

Nietzsche, Friedrich. Twilight of the Idols. Harmondsworth: Penguin, 1983.

Steiner, Peter. The Deserts of Bohemia: Czech Fiction and Its Social Context. Ithaca, NY:

Cornell University Press, 2000.

Wolfe, Cary (ed.). Zoontologies: The Question of the Animal in Contemporary Theory and Culture. Minneapolis: University of Minnesota Press, 2002. 